\title{
PRESENCIA DE HUIDOBRO EN LA POESIA DE GONZALO ROJAS
}

Cabrito, caíste en la leche.

(Palabras órficas) ${ }^{1}$

Poeta de la generación del 38 y cometa fugaz de Mandrágora, Gonzalo Rojas ha atraído la atención de la crítica últimamente. Este interés reciente y creciente por el poeta chileno se debe a la aparición de su tercer libro, Oscuro, en 1976 y a la lectura de sus poemas en el Congreso Internacional de Literatura en Florida en 1977. Muchos estudiosos de la literatura pudieron vibrar con el sentido y el sonido de sus poemas oscuros en la proximidad del mar, no en el valle del paraíso ni en la ciudad de Dios, sino en la vieja ciudad de San Agustín.

Oscuro ha encendido el entusiasmo por Rojas y hay reseñas, notas y artículos sobre el libro. Sin embargo, su primogénito, La miseria del hombre ${ }^{2}$, no ha sido lo suficientemente estudiado fuera de Chile. Varias son las razones de esta negligencia, aunque la principal no es que el volumen sea inhallable, sino su dificultad. Un análisis de La miseria del hombre es indispensable para la valoración de la obra de Rojas, pues él es de los que escriben un libro fundamental, del cual los sucesivos son variaciones, ampliaciones, revisiones e insistencias. El poemario, cuyo título provisorio fue $E l$ fuego eterno, se compuso entre mayo y diciembre de 1946 y apareció en 1948.

1 Véase Simone Weil, Carta a un religioso (Buenos Aires: Sudamericana, 1954), p. 20. Weil considera que estas palabras órficas quizá deban relacionarse con el bautismo, ya que los antiguos consideraban la leche como si fuera hecha del semen del padre. Las incluye en un pasaje donde está hablando sobre el nuevo nacimiento y la simbólica del bautismo según las palabras de Cristo sobre el tema, y que para ella deben relacionarse con las concepciones pitagóricas y estoicas de la generación.

${ }_{2}^{2}$ Gonzalo Rojas, La miseria del hombre (Valparaíso: Imprenta Roma, 1948). Todas las citas pertenecen a esta edición. Colocamos el número de las páginas entre paréntesis. 
Una exégesis profunda de La miseria del hombre confirmaria la opinión de René de Costa, quien en un artículo reciente expresa que, «para Rojas, la poesía es creación, y en este empeño su verdadero mentor es Vicente Huidobro, cuyo retrato sirve de fondo a uno de Rojas en el frontispicio de Oscuro» ${ }^{3}$.

Pero exagerar la influencia de Huidobro, Vallejo o Neruda o los surrealistas sobre Rojas sería negar su originalidad. La tarea del verdadero poeta, del poeta original, es siempre la misma. Nabokor ha afirmado: "Derivative writers seem versatile because they imitate many others... Artistic originality has only its own self to copy» ${ }^{4}$. Como la palabra original lo sugiere, el poeta debe regresar al origen y recapitular en el momento de su creación, la creación primordial, cuando el primer poeta mago llamó al mundo de la oscuridad.

Con su teoría del Creacionismo, Huidobro buscó un rejuvenecimiento artístico y, sin saberlo quizá, buscó su modelo en el Génesis. Cedomil Goiç se ha referido exhaustivamente a este tema. Gonzalo Rojas también buscó esa renovación total de su ser y usó la táctica del regreso radical en la composición de La miseria del hombre. El deseo mítico de retornar a los orígenes está en la base del descubrimiento del verdadero ser, que existía en un estadio prelingüístico, preyoico. La búsqueda del adulto del tiempo y del paraíso perdido puede reducirse a la pregunta de Edipo: ¿Quién soy? Rojas la formula en el poema «Descenso a los infiernos» cuando dice «buscando lo que soy» (p. 62) y alude a menudo a su ceguera.

Dividido en cuatro partes, La miseria del hombre no es una mera colección de poemas, sino un poema único con un comienzo, un medio y un fin, que es a la vez un comienzo. Su estructura es cíclica, una forma adecuada para una composición preocupada con el regreso a los orígenes, a la semilla. Pero el ciclo es espiralado, con una serie de descensos al abismo, de acuerdo con las llamadas curvas místicas. Aunque cada poema es una entidad separada, el poemario es una entidad nueva, una obra de arte autónoma. Muchos de los versos en los poemas individuales son prolépticos y se relacionan con la acción general del volumen, que imita el rito del nuevo nacimiento. Por ejemplo, el último poema de la

${ }^{3}$ René de Costa, «Gonzalo Rojas: Between the Poem and the Anti-Poem», página 7 del manuscrito. La traducción es nuestra. El artículo apareció en Latin American Literary Review, núm. 12 (primavera-verano 1978).

"Vladimir Nabokov, «The Art of Fiction», The Paris Review, núm. 14, p. 97, citado por William Woodin Rowe, Nabokov's Deceptive World (New York: NUP, 1971), p. 112. 
primera parte, «EI principio y el fin», anticipa el último de la cuarta parte y del libro, «Fundación de Valparaíso».

El poemario busca su propia unidad mediante la ordenación de lo que el poeta recolecta de la memoria de su pasado personal y colectivo en el transcurso de la experiencia poética. Convergen así en una obra única que podemos llamar un bricolage inspirado, una pluralidad de voces -o de máscaras - y de eventos que se incluyen por alusiones, como el «abismo del Génesis», la caída o "pecado original», «el diluvio», el éxodo, el Hijo del Hombre, el Juicio Final, el Paraíso, el bautismo y la nueva creación o salvación. La salvación consiste en el conocimiento de sí mismo y es también creación.

La elección del número de poemas, cuarenta más uno, no es casual. Como poesía visionaria, toda palabra, número o nombre apunta a un nivel simbólico de significado que se oculta al escrutinio de la mera razón. Las referencias bíblicas, tanto del Viejo como del Nuevo Testamento, son abundantes. Para la interpretación que proponemos en este trabajo - una de las tantas posibles por su ambiguiedad-, es esencial "Yo soy el viento de su origen / que sopla donde quiere» (p. 16) del poema "La poesía es mi lengua», que proviene de Juan 3:3-8, la conversación de Cristo con Nicodemo que paraboliza el regreso a la madre para renacer y la regeneración por el espíritu. El tema del nuevo nacimiento reaparece, entre otros, en "Perdí mi juventud en los burdeles», "Crecimiento de Rodrigo Tomás», "Revelación del pensamiento», «El caos» y en «Fábula moderna», cuando ocurre el prodigio del árbol que «era un hombre», el árbol en «que por su savia discurre la corriente de los árboles clásicos / de los árboles del Renacimiento» (pp. 117-120).

E1 acto poético, la creación por la palabra, es también salvadora, curadora. Para Kierkegaard, "The spoken word is precisely the saving thing» ${ }^{5}$. La asociación entre semilla y palabra, luz y palabra, fuego y palabra, ojo y luz, luz y conocimiento, luz y ser, Uno y Todo es esencial al libro. La experiencia religiosa que alude a la regeneración espiritual por la palabra creadora como segundo nacimiento aparece en 1 Pedro 1:23: ... engendrados no de semilla corruptible, sino incorruptible, por la palabra viva y permanente de Dios.

Creo que nadie ha explorado la naturaleza de la secuencia que Rojas ha moldeado en este libro. Aunque el título como el contenido es deceptivo, socráticamente irónico, y los poemas son a veces abiertamente salvajes, $L a$ miseria del hombre es un diario espiritual, una meditación

${ }^{5}$ Søren Kierkegaard, The Concept of Dread, trad. de Walter Lowrie (Princeton: PUP, 1946), pp. 110-111. 
prolongada acerca de la vida y la muerte. Especialmente sobre la miseria y la misericordia, la pasión y el padecimiento, la compasión y el amor, el único sol implacable, la única semilla que puede vencer a la muerte. Versa, o sea, se vuelve y revuelve sobre el amor, que une los contrarios y hace posible la creación, la procreación y el lenguaje.

El abrazo de los opuestos hombre-mujer, hombre-naturaleza, vidamuerte, luz-oscuridad, yo-otro, yo-mundo, finito-infinito, vacío-plenitud, lenguaje-silencio, hombre-lenguaje, es tan íntimo que los polos no pueden distinguirse. El hombre se hace uno con el panorama («La cordillera está viva»), desaparecen las fronteras entre lo animado y lo inanimado, el objeto y el sujeto. Es un verdadero magma verbal en una inmovilidad dinámica, una unión paradójica de movimiento y stasis. El espacio y el tiempo intercambian sus atributos. No es el tiempo del reloj, sino el cósmico, circular, mítico. Por eso el segundo poema se llama «Eternidad». Es el tiempo acumulado como ocurre en la memoria, la mentalidad arcaica e infantil en los sueños. En «La poesía es mi lengua» expresa: «el tiempo de los encantos es un baile de máscaras / y nada vale rehuir su hechizo. / Las personas son máscaras, y las acciones juegos de enmascarados» (p. 15). Encanto se asocia con canto, pero también cobra el valor de conjuro, posesión. La tarea del poeta es encantarnos, pero él también está bajo un hechizo. Se trata de un proceso de magia verbal, que ha sido siempre la fuerza de la poesía.

El espacio poético del libro está gobernado por el poder transformador de los elementos, sobre todo el del fuego. La metamorfosis es la ley que gobierna y produce un universo proteico «en esa rueda inmóvil del vértigo absoluto» del que se habla en "La vuelta al mundo» (p. 95). El instrumento del poeta en el proceso creador es la palabra el Logos, y éste tiene una conexión simbólica muy antigua con el fuego, que cambia continuamente y modifica todo lo que cae bajo su contacto. El fuego es la sustancia energética que posibilita el fiat lux de la creación. En el Nuevo Testamento es símbolo del Espíritu Santo. Heráclito, a quien Rojas admiraba, llamó al fuego Logos o sustancia básica, cuya vida dependía del material mismo que destruía.

Simone Weil nos recuerda que en Heráclito aparecía una Trinidad que sólo se adivina en los fragmentos conservados, pero que se muestra en el Himno a Zeus de Cleanto, de inspiración heraclitea. Las Personas son Zeus, el Logos y el Fuego divino o Rayo. El rayo no es un instrumento de violencia, sino un fuego que suscita consentimiento y obediencia voluntaria. Es, pues, el Amor ${ }^{6}$. Estas ideas aparecen en los versos que

\footnotetext{
- Simone Weil, obra citada, p. 19.
} 
siguen: «el rayo que escribe por mi mano» (p. 11), «la zarza ardiendo arrasa mi dictada escritura» (p. 45) ${ }^{7}$, «seré bueno / ... y seré puro» / "Quiero poner / en orden este fuego en que he nacido» (p. 36), y cuando en la "Fundación de Valparaíso» «aparece / una silla fantástica en el cielo, / y allí sentado el Dios de los relámpagos / como un monte de nieve envejecido» (p. 129).

Los estoicos, herederos de Heráclito, llamaban pneuma al fuego, que era para ellos un soplo ígneo. Rojas sabe que no escribe ni crea por sí mismo, sino por inspiración, el aliento divino dentro de él, ese mismo neuma que Dios insufló en el barro que llamó Adán. En el estado de posesión, éxtasis o participacion mystique que experimenta durante su tarea, no sabe de dónde le viene ese fuego, ese daimon, si de arriba o de abajo. En "La materia es mi madre» habla de «mi alma poseída» y "la mano del demonio / me hace hablar, me acaricia, me estrangula» (p. 31).

Para Rojas, como para Heráclito, el Oscuro, la vida es un caos, un mundo en constante movimiento, un flujo; y la búsqueda del hombre no es un deseo de escaparse hacia la quietud y la contemplación. Cualquier realidad más trascendente que ésta está inevitablemente más allá del alcance humano. Por ello, lo que para otros es lo invisible, lo último, lo indemne, lo absoluto o lo puro, como una dimensión del ser que está más allá y que se puede manifestar de repente sin que nos sorprenda que el velo que lo envolvía se rasgue de pronto, ese más allá es para Rojas un más acá, es «lo concreto y puro» de «La cordillera está viva». Puro se relaciona con fuego (en griego pyr), concreto tiene que ver con crear. El verbo latino creare significa crear, engendrar. Es la forma transitiva del verbo cresco, crecer. Lo concreto es lo que ha crecido junto, naturalmente. Para la imaginación judeocristiana, renovación significa no sólo empezar de nuevo, sino crecimiento y desarrollo.

La miseria del hombre es una recolección de fragmentos que refleja la imagen de un mundo quebrado. Aunque usa palabras concretas, es poesía visionaria que surge de la duda fundamental de la realidad y de la división artificial entre mente y cuerpo, que se han separado, que han dejado de crecer juntos, al unísono. La ruptura de la realidad se corresponde con la ruptura del lenguaje, por eso el poeta alude a su lengua tartamuda en el primer poema. El lenguaje puede ser adecuado para des-

${ }^{7}$ Huidobro dedicó pasajes al tema del fuego, las lenguas de fuego y la zarza ardiendo en su novela Papá o el diario de Alicia Mir, en Obras completas, tomo II (Santiago: Zig-Zag, 1964), pp. 1296 y 1303. El tema de la zarza ardiendo proviene de Exodo 3:2-3. Las palabras de Dios a Moisés «Soy el que soy», de Exudo, 3:14, aparecen en el poema «El fuego eterno» (p. 69), de La miseria del hombre. 
cribir el mundo familiar, pero defectuoso para comunicar el mundo de la visión.

A pesar de la desconfianza general de los escritores por la doblez del lenguaje, Rojas necesita usarlo y la experiencia le enseña a reconocer su poder. Trata de evocar imágenes y emociones que correspondan a su visión interior. Sabe que el hombre no puede saltar fuera del lenguaje que se da en el tiempo, como tampoco puede saltar fuera del tiempo sin morirse. Resuelve el problema espacializando el tiempo. Como en el cubismo en pintura, sobre todo el cubismo órfico, los fragmentos se convierten en los materiales de una nueva realidad que él no ha encontrado en el mundo, pero que se siente empujado a crear por sí mismo. Los pasajes que parecen más realistas son inventados y los elementos creados del volumen. En «Drama pasional», el protagonista, un pintor, después de asesinar a su amada, se pone el cañón del revólver en la boca y se larga con ella en los brazos al vacío. Cuando yacen en el pavimento, ese cuadro de cuerpos destrozados es una obra maestra. El salto al vacío es el que le permite al artista obtener el objeto de su pasión. Pero exige coraje y el enfrentamiento con la muerte. Rojas lo sabe, y en «La poesía es mi lengua» dice: «Mi creación es mi pasión», o sea, mi obra es mi padecimiento, la causa de mi sufrimiento y de mi muerte, pero también el objeto de mi amor, mi alegría y mi razón de vivir.

En «La libertad» invoca el tema de la creación. Como si fuera discípulo de Huidobro, expresa: «... ¿Por qué / Dios y no yo? / ¿Por qué yo no he creado el mundo? / ¿Por qué he de verlo todo como esclavo?» (p. 19). Hay aquí un eco del non serviam, la rebeldía del poeta demoníaco, del demiurgo que quiere competir con el creador, su celo de Dios que creó antes que él. Pero el mundo ya ha sido creado. Lo único que podrá hacer es recrear el mundo y recrearse imitando la naturaleza en sus procedimientos. "Nature - dice T. de Chardin - is the equivalent of 'becoming', self-creation: this is the view to which experience irresistibly leads us» ${ }^{8}$.

Inarticulado, agresivo, rebelde, el yo lírico parece un héroe épico, un hombre de acción, un constructor; por eso a menudo usa la palabra mano. El será el hijo de su obra. Ciego, tartamudo, en un nudo ciego que le impide la vista - pero no la visión - y le ata la lengua, parece arrojado en un limbo donde la vida y la muerte se dan juntas. Su tarea es crear su propio mundo, que dependerá de sí mismo: darse a sí mismo a luz, alumbrarse sin padre ni madre terrenos. La autocreación involucra

\footnotetext{
${ }^{8}$ Pierre Teilhard de Chardin, The Future of Man (New York: Harper \& Row, 1964), pp. 12-13.
} 
el aumento, no la disminución de la conciencia. Emplea la ceguera como símbolo del no-ser, la videncia a la que aspira como símbolo del ser. Diotima, en El banquete, afirma que toda actividad que determina el paso del no ser al ser es poiesis.

En La miseria del hombre no se trata de una creación ontológica, sino ética. En «Revelación del pensamiento», Rojas rechaza la idea de Dios como ayudante del hombre, pues una vez creado, su tarea debe hacerla solo. Esta es la miseria y a la vez la grandeza del hombre. Cuando dice «por eso veo claro que Dios es cosa inútil» (p. 66), no es una negación, sino la afirmación de la miseria y desesperación del hombre aislado de la tradicional consolación de Dios, que debe enfrentar el mundo-caos solo.

Con su lengua tartamuda, Rojas busca el modo de hablar del caos al que ha sido lanzado, para así restaurar la armonía y resolver el dualismo y la mutilación que sufre en el primer poema, «El sol y la muerte»: «fui arrojado / al mundo por dos madres, y en dos fui concebido» (p. 11). Como «the uncreating word» de Pope, con la que en La Dunciada $I V$ alude al triunfo del caos, la lengua tartamuda deshace la creación y enrolla la película de la experiencia hacia atrás, a contrapelo, al revés. En su regresión heroica retorna al estado de lo increado, de lo informe, de lo cual procede toda creación. Ciego, atraviesa la noche oscura del alma, la nada mística por la que los poetas deben pasar para rescatar la creatividad desde las sombras órficas.

En su regresión a la oscuridad primera llega a algo comparable a la Palabra del Principio de la que habla San Juan, la palabra fundadora, y a la restauración del silencio del comienzo. El último poema, «Fundación de Valparaíso», repite un acto de fundación ancestral. Sirve de correlato objetivo para expresar la armonía interior ${ }^{9}$. Sólo el héroe que se integra a sí mismo puede llegar a la posesión del objeto sagrado, el reino de Dios, pero no en el cielo o en algún lugar remoto alejado de la tierra. Este "valle del paraíso" es su paraíso terrenal, es concreto, tiene una realidad geográfica y es accesible antes de la muerte por una victoria sobre sí mismo.

El final implica su triunfo sobre la alienación de la luz, cuando sumergido en el mar los pájaros marcan un sol en su frente. Valparaíso es una zona sagrada en el mar en donde empieza una nueva vida. Pero en

9 Logos quicre decir relación y es sinónimo de arithmós, número en Platón y los pitagóricos. Para Simone Weil, obra citada, pp. 51-52, relación, proporción, armonia y mediación son sinónimos. Por ello traduce "Al principio era el Verbo» por «En el principio era la Mediación». Esto explicaría el adjetivo matemática en «Fundación de Valparaíso» cuando se alude a «La noche matemática» (p. 129). 
vez de dejarnos con una imagen alada, presenta al yo lírico mordiendo la tierra como el niño recién nacido que se aferra a los pechos de su madre para sacar de ella su fuerza, su sustancia y su vida. Cuando el poeta termina con «Te morderá mi boca / por los siglos terrestres» (página 130), retorna al estado prelingüístico, preyoico, cuyo abandono generó el lenguaje y al cual toda actividad, incluyendo el lenguaje, se inclina secretamente para que retorne.

Lilia Dapaz Strout

Universidad de Puerto Rico. 